\title{
Radiologic Definition of Sarcopenia in Chronic Liver Disease
}

\author{
Chul-min Lee (D), Bo Kyeong Kang and Mimi Kim* \\ Department of Radiology, College of Medicine, Hanyang University, Seoul 04763, Korea; \\ 2200193@hyumc.com (C.-m.L.); msbbogri@naver.com (B.K.K.) \\ * Correspondence: bluefish01@hanyang.ac.kr
}

check for

updates

Citation: Lee, C.-m.; Kang, B.K.; Kim, M. Radiologic Definition of Sarcopenia in Chronic Liver Disease. Life 2021, 11, 86. https://doi.org/ $10.3390 /$ life11020086

Received: 16 December 2020

Accepted: 21 January 2021

Published: 25 January 2021

Publisher's Note: MDPI stays neutral with regard to jurisdictional claims in published maps and institutional affiliations.

Copyright: (c) 2021 by the authors. Licensee MDPI, Basel, Switzerland. This article is an open access article distributed under the terms and conditions of the Creative Commons Attribution (CC BY) license (https:// creativecommons.org/licenses/by/ $4.0 /)$.

\begin{abstract}
Sarcopenia is prevalent in patients with chronic liver disease, and affected patients tend to have worse clinical outcomes and higher mortality. However, relevant analyses are limited by heterogeneity in the definition of sarcopenia and in the methodological approaches in assessing it. We reviewed several radiologic methods for sarcopenia in patients with chronic liver disease. Dual energy X-ray absorptiometry (DXA) can measure muscle mass, but it is difficult to evaluate muscle quality using this technique. Computed tomography, known as the gold standard for diagnosing sarcopenia, enables the objective measurement of muscle quantity and quality. The third lumbar skeletal muscle index (L3 SMI) more accurately predicted the mortality of subjects than the psoas muscle index (PMI). Few studies have evaluated the sarcopenia of chronic liver disease using ultrasonography and magnetic resonance imaging, and more studies are needed. Unification of the measurement method and cut-off value would facilitate a more systematic and universal prognosis evaluation in patients with chronic liver disease.
\end{abstract}

Keywords: sarcopenia; chronic liver disease; radiologic evaluation; DXA; CT; ultrasonography; MRI

\section{Introduction}

Sarcopenia is defined as reduced skeletal muscle mass and reduced muscle functionality [1]. Primary sarcopenia is a naturally occurring phenomenon with aging; however, when its severity is due to chronic illness beyond what can be justified by aging alone, it is called secondary sarcopenia [2]. It is also prevalent in patients with chronic liver disease. Sarcopenia is associated with a higher incidence of hepatocellular carcinoma, significant liver fibrosis, hepatic encephalopathy after transjugular intrahepatic portosystemic shunt (TIPS), high list mortality, postoperative mortality, and complications in patients with endstage liver disease [3-5]. Sarcopenia is recognized as a disease entity in the International Classification of Disease (ICD-10) [6].

Despite growing research on sarcopenia, progress is hampered by the lack of unified definitions. Several imaging modalities, such as dual energy X-ray absorptiometry (DXA), ultrasonography (US), computed tomography (CT), and magnetic resonance imaging (MRI) have made it possible to use body composition assessments for patients with chronic liver disease. Measuring muscle mass with several forms of imaging is less affected by acute illness or cognitive dysfunction compared with measuring strength or physical performance and can be objectively employed in clinical practice [7]. This review evaluates studies related to the definitions of, and methodological approaches to diagnose, sarcopenia in adults with chronic liver disease.

\section{Methods to Evaluate the Quantity and/or Quality of Skeletal Muscle Mass in Chronic Liver Disease}

2.1. DXA

Measurements of skeletal mass are provided by DXA, which allows for the quantification of three body compartments (bone mass, fat mass, and bone fat-free mass (or lean mass)) based upon the differential tissue attenuation of X-ray photons (Figure 1). 

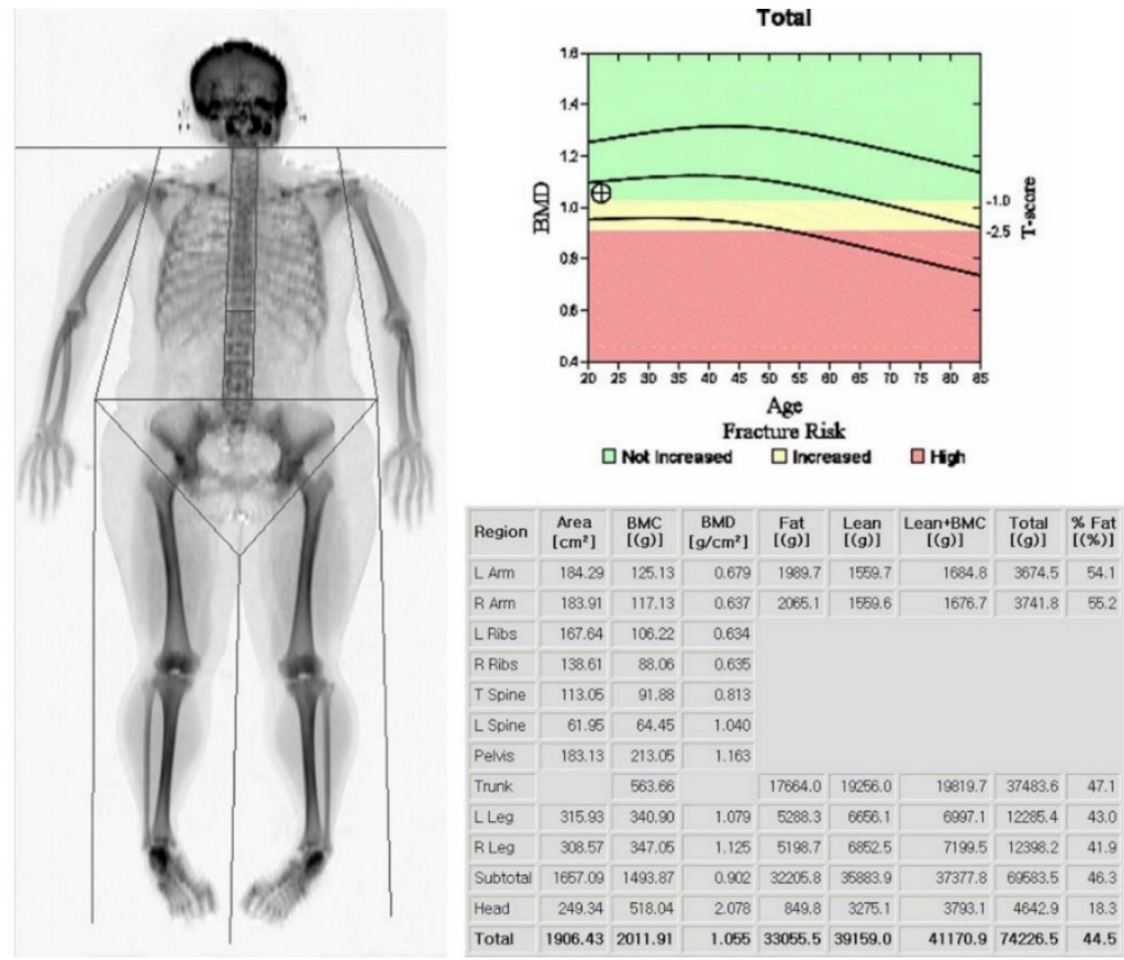

Figure 1. Dual energy X-ray absorptiometry (DXA) scan with body composition analysis. The subject's height was $1.59 \mathrm{~m}$, and the lean and appendicular lean masses were 39.1 and $16.6 \mathrm{~kg}$, respectively. The Appendicular Lean Mass Index (ALMI) was calculated as $6.6 \mathrm{~kg} / \mathrm{m}^{2}$.

Lean mass includes muscle and other components such as skin, tendons, and connective tissues. DXA is biased by the fluid overload that is frequently present in decompensated cirrhosis [8]. Lean mass, moreover, cannot differentiate muscle from water and can be overestimated in patients with cirrhosis who are experiencing water retention, such as ascites and peripheral edema. To minimize confounding by the fluid, both appendicular (arms and legs) and upper limb lean masses have been proposed as tools to analyze the muscle mass in cirrhosis [9]. The abdominal compartment is excluded from appendicular skeletal muscle measurements. This approach may not be influenced by ascites and thus may be useful for skeletal muscle mass estimations in patients with cirrhosis [10]. Low lean mass and appendicular limb lean mass assessed by DXA predict the risk of muscle weakness and limited mobility but are not associated with significant clinical outcomes, such as mortality [11]. Muscle mass is correlated with body size. The International Society for Clinical Densitometry recommended adjusting these values to body size. Muscle mass can be adjusted by height [9], weight [12], or body mass index (BMI) [13,14], although it is not known which of these methods is superior. The appendicular skeletal mass index (ASMI), adjusted by height, is calculated as follows:

$$
\text { Appendicular skeletal mass index }(\text { ASMI })=\frac{\text { Appendicular skeletal mass }(\mathrm{Kg})}{\operatorname{height}(\mathrm{m}) \times \operatorname{height}(\mathrm{m})}
$$

Lindqvist et al. noted that ASMI showed similar results to SMI (skeletal muscle index) based on CT $(\gamma=0.66, p<0.001)$, but the correlation between the lean mass index and SMI was weaker $(\gamma=0.29, p=0.035)$ and falsely high in patients with ascites in the image analysis of patients before liver transplantation (LT) [15]. To date, several consensus definitions using DXA have been proposed by the International Working Group on Sarcopenia (IWGS), Asian Working Group for Sarcopenia (AWGS), and European Working Group on Sarcopenia in Older People (EWGSOP) (Table 1) $[1,16,17]$. The cut-off 
was based on the general population and should also be validated in patients with chronic liver disease (Table 1).

Table 1. Recommended cut-off values for muscle mass using dual energy X-ray absorptiometry (DXA).

\begin{tabular}{cccc}
\hline & IWGS, 2011 & AWGS, 2014 & EWGSOP, 2018 \\
\hline \multirow{2}{*}{ ASMI } & $7.23 \mathrm{~kg} / \mathrm{m}^{2}$ for men & $7.0 \mathrm{~kg} / \mathrm{m}^{2}$ for men & $7.0 \mathrm{~kg} / \mathrm{m}^{2}$ for men \\
& $5.67 \mathrm{~kg} / \mathrm{m}^{2}$ for women & $5.4 \mathrm{~kg} / \mathrm{m}^{2}$ for women & $5.5 \mathrm{~kg} / \mathrm{m}^{2}$ for women \\
\hline
\end{tabular}

The limitation of DXA is its inability to assess muscle quality in contrast to CT and MRI. DXA cannot quantify intramuscular adipose tissue within and around muscles, and DXA-measured ASMI has shown only moderate correlation with SMI based on CT $(\gamma=0.41-0.66)$, which is considered to be the gold standard for estimating muscle mass in research $[15,18]$. Despite these limitations, DXA is commonly used in primary care in both clinical and research settings, as it has the advantages of being safe, inexpensive, and reproducible, as well as providing low radiation exposure.

\subsection{US}

US has also been applied to measure muscle size and myosteatosis. US is easy, inexpensive, and uses portable equipment, allowing it to be performed at the bedside, with no harm to the patient from radiation. US-based measurements have shown positive correlations with DXA-, CT-, and MRI-based measurements [19-21]. However, the reference standards used in each study were different, and there remains no standardization of the measurement technique. Perkisas et al. provided a standardization method for assessing appendicular muscle with US [22], but there was no clear cut-off for appendicular muscles in diagnosing sarcopenia. Only a few studies have evaluated the sarcopenia of chronic liver disease using US (Table 2).

Tandon et al. demonstrated that a nomogram based on body mass index and right thigh muscle thickness can identify male and female patients with sarcopenia defined by cross-sectional CT [23]. Hari et al. showed the possibility of using US for the evaluation of sarcopenia in patients with chronic liver disease by measuring the diameter of the right psoas muscle [24] (Figure 2). The authors reported that the success rate of measuring the psoas muscle was $72 \%$. Technical failure was due to a poor sonic window with a high abdominal circumference or the presence of ascites. US can be used as a screening tool for sarcopenia in situations where other imaging methods are not available because of their radiation, high cost, and lack of portability.

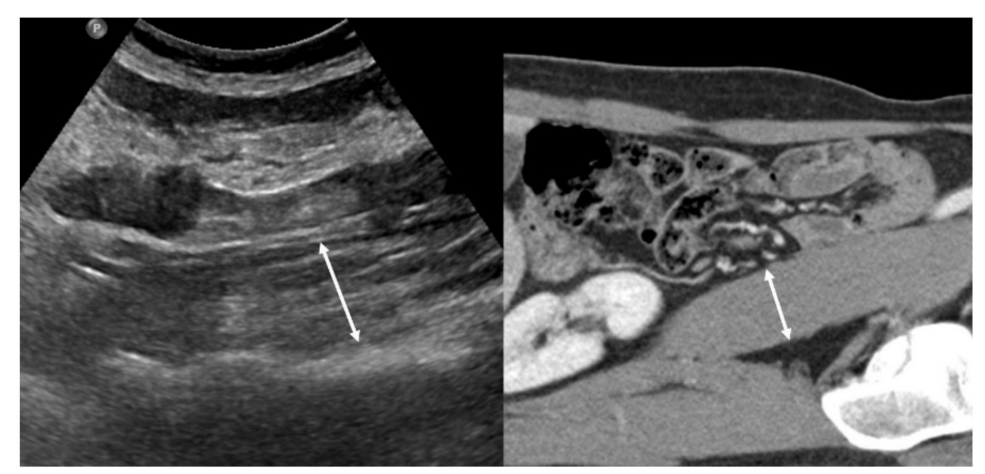

Figure 2. Left side: Example of an ultrasound measurement of the psoas muscle diameter. Right side: the corresponding CT image. 
Table 2. Summary of studies investigating radiologic sarcopenia in chronic liver disease.

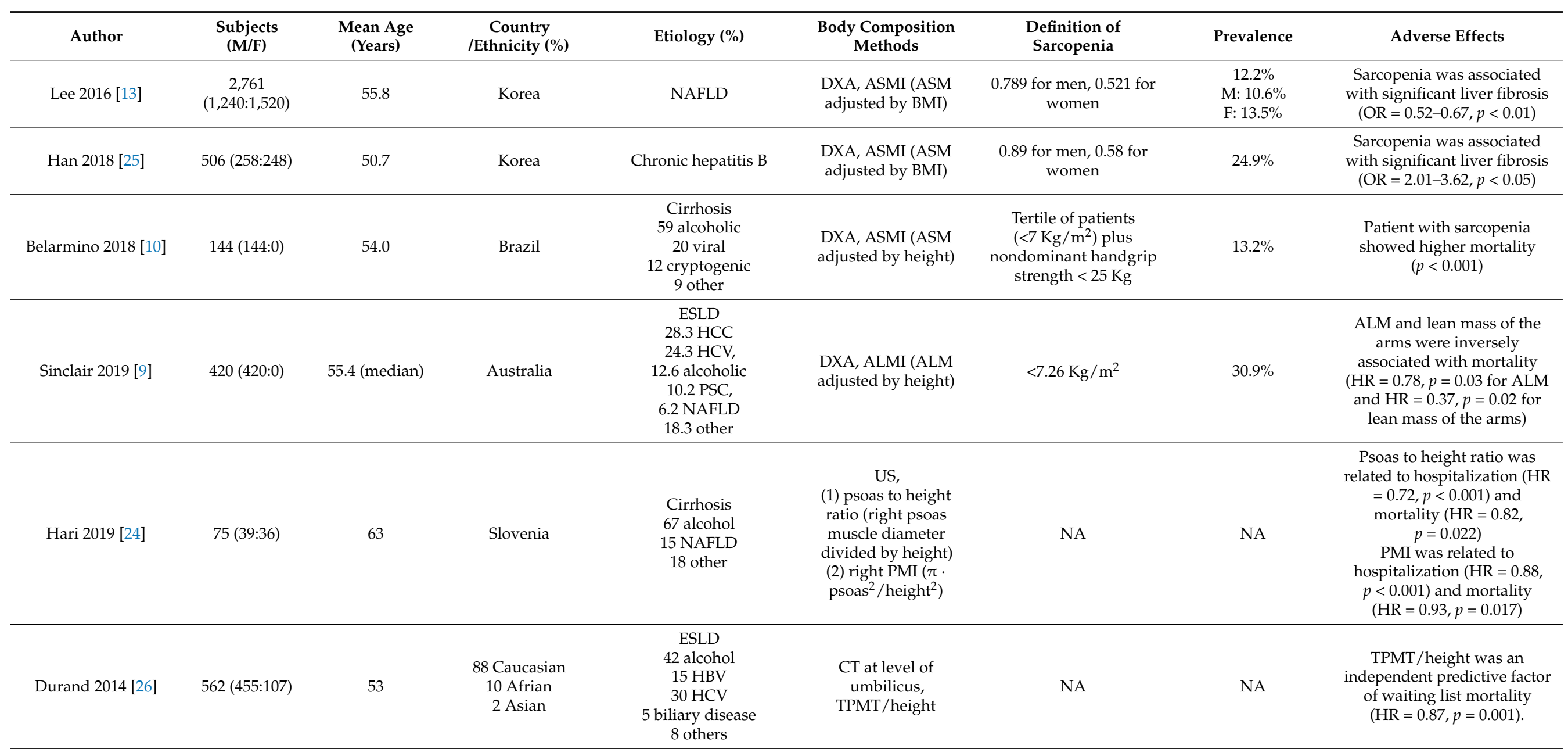


Table 2. Cont

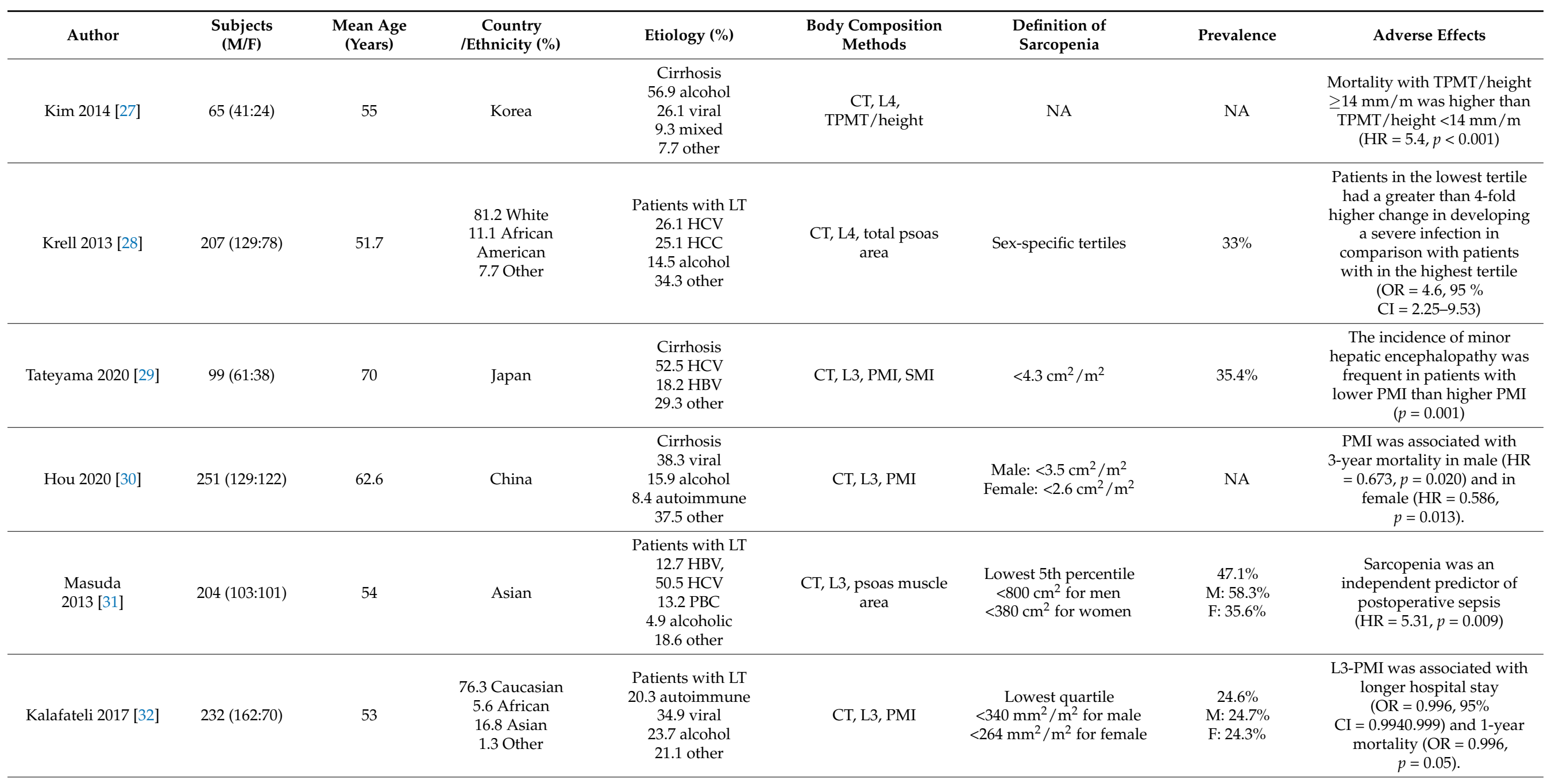


Table 2. Cont.

\begin{tabular}{|c|c|c|c|c|c|c|c|c|}
\hline Author & $\begin{array}{l}\text { Subjects } \\
(\mathrm{M} / \mathrm{F})\end{array}$ & $\begin{array}{l}\text { Mean Age } \\
\text { (Years) }\end{array}$ & $\begin{array}{c}\text { Country } \\
\text { /Ethnicity (\%) }\end{array}$ & Etiology $(\%)$ & $\begin{array}{c}\text { Body Composition } \\
\text { Methods }\end{array}$ & $\begin{array}{l}\text { Definition of } \\
\text { Sarcopenia }\end{array}$ & Prevalence & Adverse Effects \\
\hline Tsien 2014 [33] & $53(41: 12)$ & 56.9 & USA & $\begin{array}{l}\text { Patients with LT } \\
41.5 \text { viral } \\
22.6 \text { mixed } \\
7.5 \text { NASH } \\
28.3 \text { other }\end{array}$ & $\begin{array}{l}\text { CT, mid L4 level, } \\
\text { PMI and muscle } \\
\text { attenuation. }\end{array}$ & $\begin{array}{c}5^{5^{\text {th }}} \text { percentile of control } \\
\text { subjects } \\
\text { Male, }<50 \text { years old: } \\
<12.27 \mathrm{~cm}^{2} / \mathrm{m}^{2} \\
\text { Male, }>50 \text { years old: } \\
<10.12 \mathrm{~cm}^{2} / \mathrm{m}^{2} \\
\text { Female: }<50 \text { years old: } \\
<10.47 \mathrm{~cm}^{2} / \mathrm{m}^{2} \\
\text { Female: }>50 \text { years old: } \\
<10.33 \mathrm{~cm}^{2} / \mathrm{m}^{2}\end{array}$ & $\begin{array}{l}62.3 \% \text { at pre-LT } \\
86.8 \% \text { at post-LT }\end{array}$ & $\begin{array}{c}\text { Pre-LT sarcopenia increased } \\
\text { mortality }(p=0.06) . \\
\text { Continued sarcopenia in } \\
\text { post-LT showed a trend of } \\
\text { higher mortality }(p=0.08)\end{array}$ \\
\hline Tanai 2016 [34] & $149(82: 37)$ & 65 & Japan & $\begin{array}{l}\text { Cirrhosis } \\
53.0 \mathrm{HCV} \\
22.8 \text { alcohol } \\
6.7 \mathrm{HBV} \\
17.4 \text { other }\end{array}$ & CT, L3 level, SMI & $\begin{array}{l}<52.4 \mathrm{~cm}^{2} / \mathrm{m}^{2} \text { for men } \\
<38.5 \mathrm{~cm}^{2} / \mathrm{m}^{2} \text { for women }\end{array}$ & $\begin{array}{l}63 \% \\
\text { M: } 76 \% \\
\text { F: } 48 \%\end{array}$ & $\begin{array}{c}\text { Relative change in skeletal } \\
\text { muscle area }(<3.1 \%) \text { was } \\
\text { associated with mortality } \\
(\mathrm{HR}=2.73, p<0.001)\end{array}$ \\
\hline Nardelli 2017 [35] & $46(34: 12)$ & 58.6 & Italy & $\begin{array}{l}\text { Patients with cirrhosis } \\
\text { received TIPS }\end{array}$ & $\begin{array}{c}\text { CT, L3-4 disc space, } \\
\text { SMI }\end{array}$ & Same as above & $57 \%$ & $\begin{array}{c}\text { Sarcopenia was associated } \\
\text { with development of hepatic } \\
\text { encephalopathy after TIPS } \\
(\mathrm{HR}=3.13, p<0.001)\end{array}$ \\
\hline
\end{tabular}


Table 2. Cont.

\begin{tabular}{|c|c|c|c|c|c|c|c|c|}
\hline Author & $\begin{array}{l}\text { Subjects } \\
(\mathrm{M} / \mathrm{F})\end{array}$ & $\begin{array}{l}\text { Mean Age } \\
\text { (Years) }\end{array}$ & $\begin{array}{c}\text { Country } \\
\text { /Ethnicity (\%) }\end{array}$ & Etiology $(\%)$ & $\begin{array}{c}\text { Body Composition } \\
\text { Methods }\end{array}$ & $\begin{array}{c}\text { Definition of } \\
\text { Sarcopenia }\end{array}$ & Prevalence & Adverse Effects \\
\hline $\begin{array}{c}\text { Montano-Loza } 2016 \\
\text { [37] }\end{array}$ & $678(457: 221)$ & 57 & Canada & $\begin{array}{c}\text { Cirrhosis } \\
40 \mathrm{HCV} \\
23 \text { alcohol } \\
14 \text { NASH and } \\
\text { cryptogenic } \\
8 \text { autoimmune } \\
6 \text { HBC } \\
1 \text { other }\end{array}$ & $\begin{array}{l}\mathrm{CT}, \mathrm{L} 3, \mathrm{SMI} \text { and } \\
\text { muscle attenuation }\end{array}$ & Same as above & $\begin{array}{c}\text { Sarcopenia: } 43 \% \\
\text { Poor muscle } \\
\text { quality: } 52.1 \%\end{array}$ & $\begin{array}{c}\text { Sarcopenia }(\mathrm{HR}=2, p<0.001) \\
\text { and poor muscle quality } \\
(\mathrm{HR}=1.42, p=0.04) \text { were } \\
\text { associated with mortality. }\end{array}$ \\
\hline Ebadi 2018 [39] & $353(246: 107)$ & 56 & USA & ESLD & CT, L3, PMI and SMI & $\begin{array}{c}\text { SMI } \\
<50 \mathrm{~cm}^{2} / \mathrm{m}^{2} \text { for men } \\
<39 \mathrm{~cm}^{2} / \mathrm{m}^{2} \text { for women } \\
\text { PMI (cut-off calculated } \\
\text { from subjects) } \\
<5.1 \mathrm{~cm}^{2} / \mathrm{m}^{2} \text { for men } \\
<4.3 \mathrm{~cm}^{2} / \mathrm{m}^{2} \text { for women }\end{array}$ & $\begin{array}{c}\text { Sarcopenia by SMI: } \\
47 \% \\
\text { M: } 51 \% \\
\text { F: } 36 \%\end{array}$ & $\begin{array}{c}\text { In women, both low SMI and } \\
\text { PMI were predictors of } \\
\text { mortality (HR }=2.05, p=0.05 \\
\text { for low SMI and HR }=2.47, \\
p=0.01 \text { for low PMI). } \\
\text { In men, low SMI was only } \\
\text { significant predictor of } \\
\text { mortality (HR }=2.46, \\
\quad p=0.002) .\end{array}$ \\
\hline Fujiwara 2015 [40] & $1,257(828: 429)$ & 68.6 & Japan & $\begin{array}{c}\text { Patients with HCC } \\
\text { 71.2 HCV } \\
\text { 11.3 HBV } \\
\text { 17.5 other }\end{array}$ & $\begin{array}{l}\mathrm{CT}, \mathrm{L} 3, \mathrm{SMI} \text { and } \\
\text { muscle attenuation }\end{array}$ & $\begin{array}{c}\text { Muscle mass } \\
<36.2 \mathrm{~cm}^{2} / \mathrm{m}^{2} \text { for men } \\
<29.6 \mathrm{~cm}^{2} / \mathrm{m}^{2} \text { for women } \\
\text { Reduced muscle } \\
\text { attenuation } \\
<44.4 \mathrm{HU} \text { for men } \\
<39.3 \mathrm{HU} \text { for women }\end{array}$ & $\begin{array}{c}\text { Sarcopenia: } 11.1 \% \\
\text { M: } 11.6 \% \\
\text { F: } 10.0 \% \\
\text { Poor muscle } \\
\text { quality: } 85.0 \%\end{array}$ & $\begin{array}{c}\text { Sarcopenia }(\mathrm{HR}=1.52 \\
p=0.001) \text { and poor muscle } \\
\text { quality }(\mathrm{HR}=1.34, p=0.020) \\
\text { were significant predictors of } \\
\text { survival. }\end{array}$ \\
\hline Beer 2020 [41] & 265 (164:101) & 54 & Austria & $\begin{array}{l}\text { CLD } \\
21 \mathrm{HCV} \\
19 \text { alcohol } \\
9 \mathrm{HBV}\end{array}$ & $\begin{array}{c}\text { MR, L3, } \\
\text { TPAM/height }\end{array}$ & $\begin{array}{l}<12 \mathrm{~mm} / \mathrm{m} \text { for men } \\
<8 \mathrm{~mm} / \mathrm{m} \text { for women }\end{array}$ & $27.2 \%$ & $\begin{array}{c}\text { Sarcopenia was risk factor for } \\
\text { mortality }(\mathrm{HR}=2.76 \\
p=0.045) \text { for compensatory } \\
\text { advanced chronic liver } \\
\text { disease. }\end{array}$ \\
\hline
\end{tabular}


Table 2. Cont.

\begin{tabular}{|c|c|c|c|c|c|c|c|c|}
\hline Author & $\begin{array}{l}\text { Subjects } \\
(\mathbf{M} / \mathrm{F})\end{array}$ & $\begin{array}{l}\text { Mean Age } \\
\text { (Years) }\end{array}$ & $\begin{array}{c}\text { Country } \\
\text { /Ethnicity (\%) }\end{array}$ & Etiology $(\%)$ & $\begin{array}{c}\text { Body Composition } \\
\text { Methods }\end{array}$ & $\begin{array}{c}\text { Definition of } \\
\text { Sarcopenia }\end{array}$ & Prevalence & Adverse Effects \\
\hline Praktiknjo 2018 [42] & $116(69: 47)$ & 59 & $\mathrm{EU}$ & $\begin{array}{l}\text { Patients with cirrhosis } \\
\text { received TIPS } \\
62.9 \text { alcohol } \\
15.5 \text { viral } \\
21.6 \text { other }\end{array}$ & $\begin{array}{c}\text { MR, at level of SMA, } \\
\text { spinae muscle area } \\
\text { and fat-free muscle } \\
\text { area }\end{array}$ & $\begin{array}{l}\text { Sex specific cut-off from } \\
\text { subjects } \\
\text { Total muscle }<3523 \mathrm{~mm}^{2} \\
\text { and fat-free muscle } \\
<3197 \mathrm{~mm}^{2} \text { for men } \\
\text { Total muscle }<3153 \mathrm{~mm}^{2} \\
\text { and fat-free muscle } \\
<2895 \mathrm{~mm}^{2} \text { for women }\end{array}$ & $44.0 \%$ & $\begin{array}{l}\text { Persistence of sarcopenia } \\
\text { after TIPS is associated with } \\
\text { mortality }(\mathrm{HR}=5.62 \\
p=0.001)\end{array}$ \\
\hline
\end{tabular}




\subsection{CT}

CT imaging is increasingly used as the gold standard to quantify skeletal muscle mass along with MRI and constitutes a good resource for the objective identification of sarcopenia. However, CT suffers from the disadvantage of radiation exposure. Nevertheless, patients with chronic liver disease frequently receive CTs to evaluate hepatocellular carcinoma or the complications of portal hypertension.

Generally, the cross-sectional areas of the psoas or abdominal muscle mass of the third (L3) or fourth (L4) lumbar vertebra levels that are not affected by activity are used. Although the cross-sectional area of the level of the umbilicus has previously been used [26], this area may be measured at different levels of the vertebra. Moreover, the umbilicus may become flat and unable to be found on axial CTs in patients with ascites or obesity [43]. Measuring should be conducted at the cross-sectional area of the skeletal muscles at the level of L3, which accurately represents the whole-body skeletal muscle mass [44]. At the L3 transverse section, muscle groups include the rectus abdominis, transverse abdominis, internal and external obliques, quadratus lumborum, psoas major and minor, and erector spinae. These measurements were computed by summing the tissue pixels and multiplying them by the pixel surface area. A threshold range of 29 to $150 \mathrm{HU}$ is commonly used to define the muscle (Figure 3).
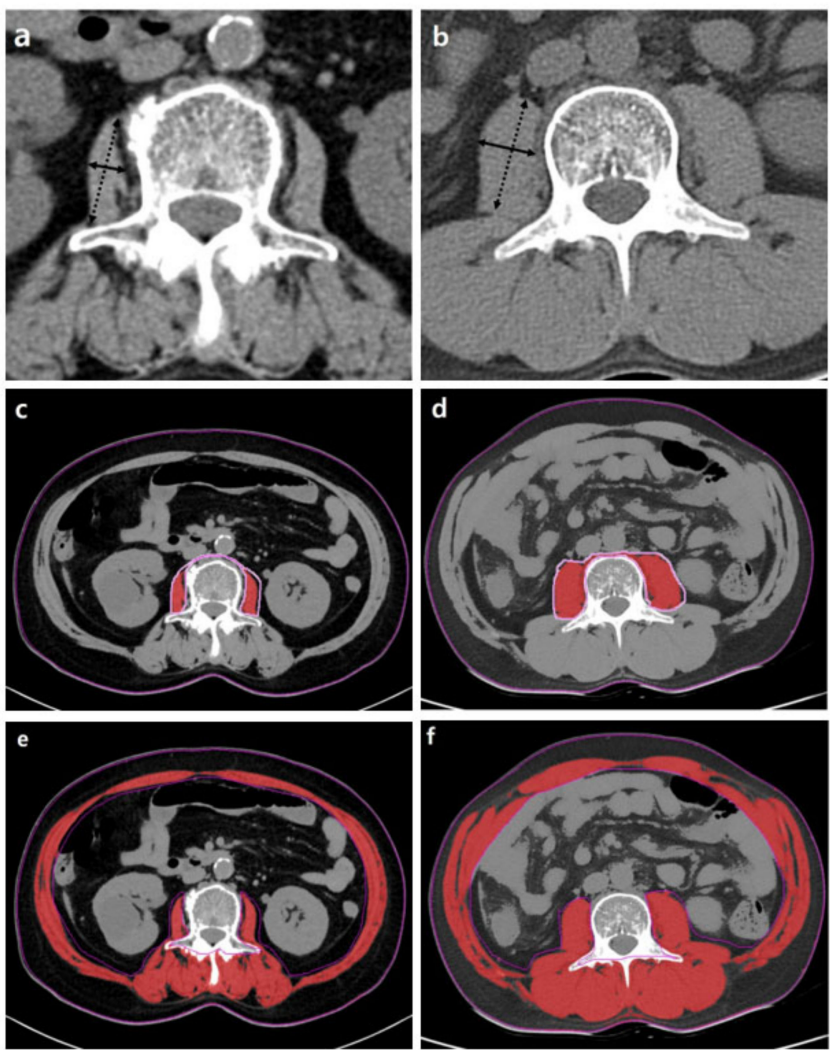

Figure 3. Abdominal CT images taken at the third lumbar vertebra with cirrhosis applied to quantify transverse psoas muscle thickness (TPMT), psoas muscle, and total muscle areas. The psoas muscle in panels $(\mathbf{c}, \mathbf{d})$ and total muscle area in panels $(\mathbf{e}, \mathbf{f})$ are colored in red. Panels $(\mathbf{a}, \mathbf{c}, \mathbf{e})$ present a female patient with low TPMT $(5.9 \mathrm{~mm} / \mathrm{m})$, psoas muscle index (PMI) $\left(2.3 \mathrm{~cm}^{2} / \mathrm{m}^{2}\right)$, and skeletal muscle index (SMI) $\left(35.7 \mathrm{~cm}^{2} / \mathrm{m}^{2}\right)$. Panels $(\mathbf{b}, \mathbf{d}, \mathbf{f})$ present a male patient with high TPMT $(23.3 \mathrm{~mm} / \mathrm{m})$, PMI $\left(6.8 \mathrm{~cm}^{2} / \mathrm{m}^{2}\right)$, and SMI $\left(51.6 \mathrm{~cm}^{2} / \mathrm{m}^{2}\right)$. The mean density of muscle in $(\mathbf{c}-\mathbf{f})$ is $34.7,38.2,26.2$, and $36.6 \mathrm{HU}$, respectively. 
Most of the measured area is corrected with height and sometimes with BMI [45]. Height correction is necessary to determine the relative muscle mass because of the linear relationship between skeletal muscle and height [46]. The SMI is calculated as follows:

$$
\text { Skeletal muscle index (SMI) of L3 }=\frac{\text { Total muscle area of L3 level }\left(\mathrm{cm}^{2}\right)}{\text { height }(\mathrm{m}) \times \operatorname{height}(\mathrm{m})}
$$

Occasionally, the psoas muscle is selected from other skeletal muscles of the region because it is located centrally, is easily identified, and is not directly affected by abdominal distension in the presence of ascites. There are several methods for measuring the area of the psoas muscle:

(1) Transverse psoas muscle thickness (TPMT), where the greatest transverse diameter of the psoas muscle runs perpendicular to the long axis (anterior-posterior oblique) of the psoas muscle diameter [27]. The results were normalized to body height and are shown as $\mathrm{mm} / \mathrm{m}$ :

$$
\mathrm{TPMT} / \text { height }=\frac{\text { Transverse psoas muscle thickness }(\mathrm{mm})}{\text { height }(\mathrm{m})}
$$

(2) The psoas muscle index (PMI), where the estimated or measured psoas muscle area is adjusted by height [33]. The estimated psoas muscle area is the sum of the product of the long axis and the short axis of the iliopsoas muscles on both sides [2]. The estimated psoas muscle area and PMI are calculated as follows:

$$
\text { Estimated psoas muscle area }=(\mathrm{a} \times \mathrm{b})+(\mathrm{c} \times \mathrm{d})
$$

where $\mathrm{a}$ is the TPMT of the right psoas muscle, $\mathrm{b}$ is the longitudinal psoas muscle thickness (LPMT) of the right psoas muscle, $\mathrm{c}$ is the TPMT of the left psoas, and $\mathrm{d}$ is the LPMT of the left psoas muscle.

$$
\text { Psoas muscle index }(\mathrm{PMI}) \text { of L3 }=\frac{\text { Total psoas muscle area of L3 level }\left(\mathrm{cm}^{2}\right)}{\operatorname{height}(\mathrm{m}) \times \operatorname{height}(\mathrm{m})}
$$

A consensus definition using PMI was proposed by the Japan Society of Hepatology guidelines for sarcopenia. This definition includes a cut-off value for the measured psoas muscle area of $6.36 \mathrm{~cm}^{2} / \mathrm{m}^{2}$ in males and $3.92 \mathrm{~cm}^{2} / \mathrm{m}^{2}$ in females and a cut-off value for the estimated psoas muscle of $6.0 \mathrm{~cm}^{2} / \mathrm{m}^{2}$ in males and $3.4 \mathrm{~cm}^{2} / \mathrm{m}^{2}$ in females [2] . Other studies used the cut-off value derived from mortality or morbidity $[29,30,39]$ or from the sex-specific lowest quartile or fifth percentile of the subjects [32,33].

However, there is no evidence confirming that the cross-sectional area of the psoas muscles has a good correlation with the whole-lumbar or the whole-body muscle volume. Among 396 patients with end-stage liver disease, PMI was less likely to predict mortality than SMI in male patients. Male patients who died had a lower SMI but not a lower PMI compared to male patients who were alive [39]. Therefore, the entire skeletal muscle at the L3 vertebra level should be measured.

The attenuation of muscle was additionally measured to evaluate muscle quality. Low muscle attenuation, referred to as myosteatosis, indicates increased intramuscular fat content, which contributes to muscle weakness independent of the age-associated loss in muscle mass [47,48]. Wang et al. showed that myosteatosis, but not muscle mass, is related to mortality in a study of 292 patients with end-stage liver disease [36].

The same cut-off value cannot be uniformly applied because the muscle mass varies according to age, sex, BMI, and ethnicity. There is wide heterogeneity in the cut-off values of SMI used to defined sarcopenia in chronic liver disease: A sex-specific cut-off value derived in patients with solid tumors related to mortality $[34,35,49,50]$, a cut-off value according to BMI [36,37], a cut-off according to age [33], a cut-off defined from control subjects [33], and a cut-off from subjects using the sex-specific lowest quartile/tertile $[32,38,40]$. 
The North American Working group on Sarcopenia in Liver Transplantation suggested that the definition of sarcopenia in patients with end-stage liver disease waiting for LT should be defined as SMI less than $50 \mathrm{~cm}^{2} / \mathrm{m}^{2}$ for males and less than $39 \mathrm{~cm}^{2} / \mathrm{m}^{2}$ for females at the L3 level [7]. In their study, there were no statistically significant differences in SMI according to ethnicity.

\section{4. $M R I$}

MRI can also be used to evaluate muscle quantity and quality. MRI provides high resolution and permits the separation and quantification of muscle compartments and fat distribution. It can be used to evaluate detailed anatomical changes of muscle, including muscular atrophy, fatty degeneration, and edema. In contrast to CT, MRI carries no risk of ionizing radiation exposure or kidney injury due to iodine contrast media administration. MRI can be performed without the administration of contrast media because of its high soft-tissue contrast and multiparametric characteristics.

With advances in MRI techniques, the assessment of the chemical composition of tissue has also become possible. MR spectroscopy (MRS) is a representative MR technique that assesses the chemical composition of tissue [51,52]. DIXON-based MRI is a recent MRI technique challenging MRS by using a chemical shift to enable the selective reconstruction of fat signal- and water signal-only images $[53,54]$. Quantitative analysis using DIXONbased MRI showed an excellent correlation in MRS, which outperformed visual assessment in the detection of muscle fat content [55]. These fat quantification MRI techniques could be applied to the evaluation of sarcopenia in terms of muscle quality assessments in patients with chronic liver disease (Figure 4).

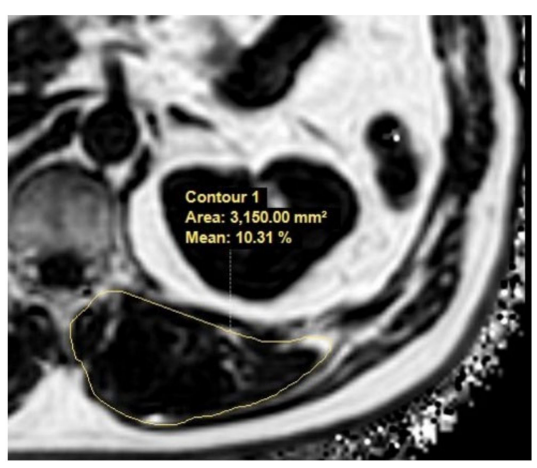

(a)

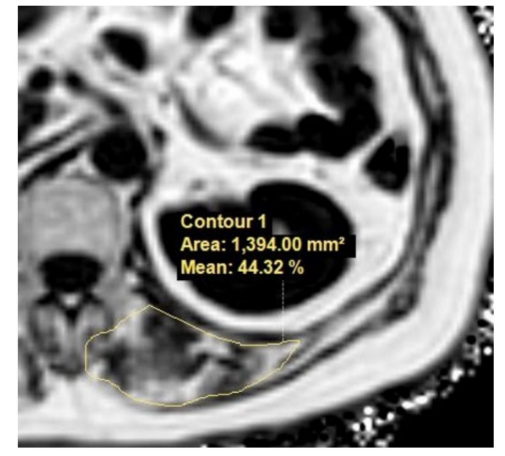

(b)

Figure 4. Example MR images (fat fraction) of cross-section of the spinal muscles at the Superior Mesenteric Artery level in two patients with low fatty degeneration (a) and high fatty degeneration (b). (a) The area and fat fraction of the left spinal muscle were $3150 \mathrm{~mm}^{2}$ and $10.3 \%$. (b) The area and fat fraction of the left spinal muscle were $1394 \mathrm{~mm}^{2}$ and $44.3 \%$. An axial three-dimensional multi-echo-modified Dixon gradient echo sequence was used for the MRI. Imaging parameters for the sequence were as follows: six Echo Time (TE)s (first TE shortest automatic (0.9-1.2ms), delta TE 0.8-1.01ms); Repetition Time (TR) shortest automatic (5.8-6.3 ms); flip angle =3; field of view = $35 \times$ $35 \mathrm{~cm}^{2} ; 3 \mathrm{~mm}$ slice thickness with no gap; matrix size $=300 \times 300$; number of slices $=60$; scan time $=$ $14.1 \mathrm{~s}$; parallel imaging SENSE factor $=2$; number of signal average $=1$. The sequence automatically produces water, fat, fat fraction, $\mathrm{R} 2 *$, and $\mathrm{T} 2 *$ maps.

Compared with CT, which is the gold standard for the evaluation of sarcopenia in several guidelines, MRI has shown similar performance in the evaluation of sarcopenia in healthy subjects $[56,57]$. Traditionally, MRIs have been used for muscle quality and quantity evaluations of neuromuscular disorders [58-60]. Furthermore, an MRI-only assessed sarcopenia is an important prognostic factor in many types of cancer, including breast cancer, head and neck cancer, and colorectal cancer [61-63]. However, this method remains in the early stages for studying sarcopenia in chronic liver disease. There are two 
studies on the adverse effects of decreased muscle mass diagnosed by TPMT-adjusted height and the spinae muscle area (Table 2) [41,42]. To our knowledge, there has been no study on the adverse effects of reduced muscle mass at the L3 level, and there is also a lack of research articles on myosteatosis in patients with chronic liver disease, so further studies and validations are needed. The concern regarding the high cost of MRI can be considered negligible because patients with chronic liver disease are frequently subjected to MRIs for several clinical reasons.

\section{Considerations for the Radiologic Evaluation of Sarcopenia}

The radiologic evaluation of sarcopenia has the advantage of being able to measure muscle mass objectively and quantitatively. CT and MRI, which are considered to be gold standards for muscle mass measurements, showed high interobserver agreement with Pearson's correlation coefficient $[39,63]$. The measurements of skeletal muscle mass on CT and MRI were also found to be interchangeable. Park et al. showed very good agreement between CT and MRI measurements of skeletal muscle mass at the level of the L3 vertebra (the ICC of reader 1 was 0.928 and that of reader 2 was 0.853) [64]. This result is also consistent with studies carried out at the level of the superior mesenteric artery (mostly the first lumbar vertebra) and the level of the third cervical vertebra (C3) [57,63]. In addition, it is possible to measure skeletal muscle retrospectively because most patients with chronic liver disease frequently undergo radiologic evaluations.

In previous studies, different cut-off values were applied according to sex, etiology of the disease, ethnicity, and the modality used. The SMI values of male patients were significantly higher than those of female patients; however, the frequency of sarcopenia among male patients was higher than that in female patients when sex-specific cut-offs were applied $[31,35,39]$. Previous studies have examined the association between non-alcoholic fatty liver disease (NAFLD) and hepatitis B or C viral cirrhosis with sarcopenia using DXA as the assessment tool $[12,13,25,65]$. A study from Korea reported the association of NAFLD with sarcopenia using CT [45], with a cut-off value defined as 1 standard deviation below the sex-specific mean value for a young healthy population: $8.37 \mathrm{~cm}^{2} /\left(\mathrm{kg} / \mathrm{m}^{2}\right)$ for men and $7.47 \mathrm{~cm}^{2} /\left(\mathrm{kg} / \mathrm{m}^{2}\right)$ for women. After the publication of the EWGSOP guidelines, some studies were designed to determine specific cut-off values for sarcopenia assessment using CT for Japanese and Asian adults. Two studies provided PMI cut-off values of 3.74 and $6.36 \mathrm{~cm}^{2} / \mathrm{m}^{2}$ for men and 2.29 and $3.92 \mathrm{~cm}^{2} / \mathrm{m}^{2}$ for women, respectively, based on Japanese liver donor data. The authors suggested that that the cut-off values in Western studies could be different from the actual values in Asian populations due to differences in body sizes, lifestyles, and ethnicities $[25,66]$. Further studies to define sarcopenia should be conducted according to ethnicity and the etiology of hepatic disease.

There is a need for standardized CT, as CT parameters such as tube potential, the use of a contrast agent, and slide thickness also affect the assessment of skeletal muscle. A reduction in tube potential from 140 to $80 \mathrm{kV}$ leads to a $5.2 \%$ decrease in SMI [67], and the use of contrast media overestimates the average SMI by up to $2.8 \%$ [68]. Differences in slice thickness of 10 and $2 \mathrm{~mm}$ can result in a 1.9\% smaller SMI [68]. Contrast enhancement, moreover, strongly influences the value of skeletal muscle density $[69,70]$.

Moreover, radiological assessment does not always reflect strength or physical performance [71-74]. However, further research is needed to determine which parameters of muscle strength and physical performance are complemented by radiological assessment. In 2018, EWGSOP recommended that if a patient has low muscle strength, is defined as probable sarcopenia, and has low muscle quantity or quality, they can be diagnosed as sarcopenia [1] because it is recognized that strength is better than muscle mass in predicting adverse outcomes. Sinclair et al. showed that the model for the end-stage liver disease (MELD)-handgrip strength bivariate Cox model is superior to the MELD-CT muscle Cox model $(p<0.001)$ in predicting mortality [18]. For muscle strength, the use of a handheld dynamometer is a valid and reliable method with high interrater and intrarater reliability. 
Further, the short physical performance battery and gait speed provide good measurement properties for the assessment of physical performance [1,75].

\section{Conclusions}

The evaluation of sarcopenia is crucial in patients with chronic liver disease, as well as other chronic illness, because sarcopenia is one of the important prognostic factors $[4,5]$. Overall, CT and MRI are considered the gold standard for evaluating sarcopenia and are frequently performed in patients with chronic liver disease for the evaluation of hepatocellular carcinoma or complications of portal hypertension. CT shows excellent performance in estimating the quality and quantity of muscle, and many studies have reported variable measurement methods and cut-off values in patients with chronic liver disease. MRI could be a competent imaging modality for muscle quality evaluation by measuring intramuscular fat content with MRS or DIXON-based MRI, as well as muscle mass by measuring the area, which requires further validations in chronic liver disease. DXA is a reliable alternative for clinical use when a CT scan is not clinically indicated or available. Unification of the measurement method and cut-off value would facilitate more systematic and universal prognosis evaluations in patients with chronic disease.

Author Contributions: Conceptualization: M.K.; data curation: C.-m.L., B.K.K.; supervision: M.K.; writing-original draft: C.-m.L.; review and editing: M.K. All authors have read and agreed to the published version of the manuscript.

Funding: This research received no external funding.

Institutional Review Board Statement: Not applicable.

Informed Consent Statement: Not applicable.

Data Availability Statement: No new data were created or analyzed in this study. Data sharing is not applicable to this article.

Acknowledgments: None of the authors have any financial relationships to disclose.

Conflicts of Interest: We declare that we have no financial and personal relationships with other people or organizations that can inappropriately influence our work, and there is no professional or other personal interest of any nature or kind in any product, service, and/or company.

\section{References}

1. Cruz-Jentoft, A.J.; Bahat, G.; Bauer, J.; Boirie, Y.; Bruyère, O.; Cederholm, T.; Cooper, C.; Landi, F.; Rolland, Y.; Sayer, A.A.; et al. Sarcopenia: Revised European consensus on definition and diagnosis. Age Ageing 2019, 48, 16-31. [CrossRef] [PubMed]

2. Nishikawa, H.; Shiraki, M.; Hiramatsu, A.; Moriya, K.; Hino, K.; Nishiguchi, S. Japan Society of Hepatology guidelines for sarcopenia in liver disease (1st edition): Recommendation from the working group for creation of sarcopenia assessment crite-ria. Hepatol. Res. 2016, 46, 951-963. [CrossRef] [PubMed]

3. Tsien, C.; Shah, S.N.; McCullough, A.J.; Dasarathy, S. Reversal of sarcopenia predicts survival after a transjugular intrahe-patic portosystemic stent. Eur. J. Gastroenterol. Hepatol. 2013, 25, 85-93. [CrossRef] [PubMed]

4. Ooi, P.H.; Hager, A.; Mazurak, V.C.; Dajani, K.; Bhargava, R.; Gilmour, S.M.; Mager, D. Sarcopenia in Chronic Liver Disease: Impact on Outcomes. Liver Transplant. 2019, 25, 1422-1438. [CrossRef] [PubMed]

5. Kim, G.; Kang, S.H.; Kim, M.Y.; Baik, S.K. Prognostic value of sarcopenia in patients with liver cirrhosis: A systematic review and meta-analysis. PLoS ONE 2017, 12, e0186990. [CrossRef] [PubMed]

6. Anker, S.D.; Morley, J.E.; von Haehling, S. Welcome to the ICD-10 code for sarcopenia. J. Cachexia Sarcopenia. Muscle 2016, 7, 512-514.

7. Carey, E.J.; Lai, J.C.; Sonnenday, C.; Tapper, E.B.; Tandon, P.; Duarte-Rojo, A.; Dunn, M.A.; Tsien, C.; Kallwitz, E.R.; Ng, V.; et al. A North American expert opinion statement on sarcopenia in liver transplantation. Hepatology 2019, 70, 1816-1829. [CrossRef]

8. Kallwitz, E.R. Sarcopenia and liver transplant: The relevance of too little muscle mass. World J. Gastroenterol. 2015, 21, 10982-10993. [CrossRef]

9. Sinclair, M.; Hoermann, R.; Peterson, A.; Testro, A.; Angus, P.W.; Hey, P.; Chapman, B.; Gow, P.J. Use of Dual X-ray Absorptiometry in men with advanced cirrhosis to predict sarcopenia-associated mortality risk. Liver Int. 2019, 39, 1089-1097. [CrossRef]

10. Belarmino, G.; Gonzalez, M.C.; Sala, P.; Torrinhas, R.S.; Andraus, W.; D'Albuquerque, L.A.C.; Pereira, R.M.R.; Caparbo, V.F.; Ferrioli, E.; Pfrimer, K.; et al. Diagnosing Sarcopenia in Male Patients with Cirrhosis by Dual-Energy X-Ray Absorptiometry Estimates of Appendicular Skeletal Muscle Mass. J. Parenter. Enter. Nutr. 2017, 42, 24-36. [CrossRef] 
11. Cawthon, P.M.; Fox, K.M.; Gandra, S.R.; Delmonico, M.J.; Chiou, C.-F.; Anthony, M.S.; Sewall, A.; Goodpaster, B.; Satterfield, S.; Cummings, S.R.; et al. Do Muscle Mass, Muscle Density, Strength, and Physical Function Similarly Influence Risk of Hos-pitalization in Older Adults? J. Am. Geriatr. Soc. 2009, 57, 1411-1419. [CrossRef] [PubMed]

12. Hong, H.C.; Hwang, S.Y.; Choi, H.Y.; Yoo, H.J.; Seo, J.A.; Kim, S.G.; Kim, N.H.; Baik, S.H.; Choi, D.S.; Choi, K.M. Relationship between sarcopenia and nonalcoholic fatty liver disease: The Korean Sarcopenic Obesity Study. Hepatology 2013, 59, 1772-1778. [CrossRef] [PubMed]

13. Lee, Y.-H.; Kim, S.U.; Song, K.; Park, J.Y.; Kim, D.Y.; Ahn, S.H.; Lee, B.-W.; Kang, E.S.; Cha, B.-S.; Han, K.-H. Sarcopenia is associated with significant liver fibrosis independently of obesity and insulin resistance in nonalcoholic fatty liver disease: Na-tionwide surveys (KNHANES 2008-2011). Hepatology 2016, 63, 776-786. [CrossRef] [PubMed]

14. Koo, B.K.; Kim, D.; Joo, S.K.; Kim, J.H.; Chang, M.S.; Kim, B.G.; Lee, K.L.; Kim, W. Sarcopenia is an independent risk factor for non-alcoholic steatohepatitis and significant fibrosis. J. Hepatol. 2017, 66, 123-131. [CrossRef]

15. Lindqvist, C.; Christensen, R.H.; Majeed, A.; Wahlin, S. Assessment of muscle mass depletion in chronic liver disease: Du-alenergy x-ray absorptiometry compared with computed tomography. Nutrition 2019, 61, 93-98. [CrossRef]

16. Fielding, R.A.; Vellas, B.; Evans, W.J.; Bhasin, S.; Morley, J.E.; Newman, A.B.; Van Kan, G.A.; Andrieu, S.; Bauer, J.; Breuille, D.; et al. Sarcopenia: An Undiagnosed Condition in Older Adults. Current Consensus Definition: Prevalence, Etiology, and Consequences. International Working Group on Sarcopenia. J. Am. Med. Dir. Assoc. 2011, 12, 249-256. [CrossRef]

17. Chen, L.-K.; Liu, L.-K.; Woo, J.; Assantachai, P.; Auyeung, T.-W.; Bahyah, K.S.; Chou, M.-Y.; Hsu, P.-S.; Krairit, O.; Lee, J.S.; et al. Sarcopenia in Asia: Consensus Report of the Asian Working Group for Sarcopenia. J. Am. Med. Dir. Assoc. 2014, $15,95-101$. [CrossRef]

18. Sinclair, M.; Chapman, B.; Hoermann, R.; Angus, P.W.; Testro, A.; Scodellaro, T.; Gow, P.J. Handgrip Strength Adds More Prognostic Value to the Model for End-Stage Liver Disease Score Than Imaging-Based Measures of Muscle Mass in Men with Cirrhosis. Liver Transplant. 2019, 25, 1480-1487. [CrossRef]

19. Thomaes, T.; Thomis, M.; Onkelinx, S.; Coudyzer, W.; Cornelissen, V.A.; Vanhees, L. Reliability and validity of the ultrasound technique to measure the rectus femoris muscle diameter in older CAD-patients. BMC Med. Imaging 2012, 12, 7. [CrossRef]

20. Abe, T.; Fujita, E.; Thiebaud, R.S.; Loenneke, J.P.; Akamine, T. Ultrasound-Derived Forearm Muscle Thickness Is a Powerful Predictor for Estimating DXA-Derived Appendicular Lean Mass in Japanese Older Adults. Ultrasound Med. Biol. 2016, 42, 23412344. [CrossRef]

21. Abe, T.; Loenneke, J.P.; Young, K.C.; Thiebaud, R.S.; Nahar, V.K.; Hollaway, K.M.; Stover, C.D.; Ford, M.A.; Bass, M.A.; Loftin, M. Validity of Ultrasound Prediction Equations for Total and Regional Muscularity in Middle-aged and Older Men and Women. Ultrasound Med. Biol. 2015, 41, 557-564. [CrossRef] [PubMed]

22. Perkisas, S.; Baudry, S.; Bauer, J.; Beckwée, D.; De Cock, A.; Hobbelen, H.; Jager-Wittenaar, H.; Kasiukiewicz, A.; Landi, F.; Marco, E.; et al. Application of ultrasound for muscle assessment in sarcopenia: Towards standardized measurements. Eur. Geriatr. Med. 2018, 9, 739-757. [CrossRef]

23. Tandon, P.; Low, G.; Mourtzakis, M.; Zenith, L.; Myers, R.P.; Abraldes, J.G.; Shaheen, A.A.M.; Qamar, H.; Mansoor, N.; Carbonneau, M.; et al. A Model to Identify Sarcopenia in Patients with Cirrhosis. Clin. Gastroenterol. Hepatol. 2016, 14, 1473-1480.e3. [CrossRef] [PubMed]

24. Hari, A.; Berzigotti, A.; Štabuc, B.; Caglevič, N. Muscle psoas indices measured by ultrasound in cirrhosis-Preliminary evaluation of sarcopenia assessment and prediction of liver decompensation and mortality. Dig. Liver Dis. 2019, 51, $1502-1507$. [CrossRef] [PubMed]

25. Han, E.; Lee, Y.-H.; Kim, B.K.; Park, J.Y.; Kim, D.Y.; Ahn, S.H.; Lee, B.-W.; Kang, E.S.; Cha, B.-S.; Han, K.-H.; et al. Sarcopenia is associated with the risk of significant liver fibrosis in metabolically unhealthy subjects with chronic hepatitis B. Aliment. Pharmacol. Ther. 2018, 48, 300-312. [CrossRef] [PubMed]

26. Durand, F.; Buyse, S.; Francoz, C.; Laouénan, C.; Bruno, O.; Belghiti, J.; Moreau, R.; Vilgrain, V.; Valla, D. Prognostic value of muscle atrophy in cirrhosis using psoas muscle thickness on computed tomography. J. Hepatol. 2014, 60, 1151-1157. [CrossRef]

27. Kim, T.Y.; Kim, M.Y.; Sohn, J.H.; Kim, S.M.; Ryu, J.A.; Lim, S.; Kim, Y. Sarcopenia as a Useful Predictor for Long-Term Mortality in Cirrhotic Patients with Ascites. J. Korean Med. Sci. 2014, 29, 1253-1259. [CrossRef]

28. Krell, R.W.; Kaul, D.R.; Martin, A.R.; Englesbe, M.J.; Sonnenday, C.J.; Cai, S.; Malani, P.N. Association between sarcopenia and the risk of serious infection among adults undergoing liver transplantation. Liver Transplant. 2013, 19, 1396-1402. [CrossRef]

29. Tateyama, M.; Naoe, H.; Tanaka, M.; Tanaka, K.; Narahara, S.; Tokunaga, T.; Kawasaki, T.; Yoshimaru, Y.; Nagaoka, K.; Watanabe, $\mathrm{T}$. Loss of skeletal muscle mass affects the incidence of minimal hepatic encephalopathy: A case control study. BMC Gastroenterol. 2020, 20, 1-10. [CrossRef]

30. Hou, L.; Deng, Y.; Wu, H.; Xu, X.; Lin, L.; Cui, B.; Zhao, T.; Fan, X.; Mao, L.; Hou, J.; et al. Low psoas muscle index associates with long-term mortality in cirrhosis: Construction of a nomogram. Ann. Transl. Med. 2020, 8, 358. [CrossRef]

31. Masuda, T.; Shirabe, K.; Ikegami, T.; Harimoto, N.; Yoshizumi, T.; Soejima, Y.; Uchiyama, H.; Ikeda, T.; Baba, H.; Maehara, Y. Sarcopenia is a prognostic factor in living donor liver transplantation. Liver Transplant. 2014, 20, 401-407. [CrossRef] [PubMed]

32. Kalafateli, M.; Mantzoukis, K.; Yau, Y.C.; Mohammad, A.O.; Arora, S.; Rodrigues, S.; De Vos, M.; Papadimitriou, K.; Thor-burn, D.; O'Beirne, J.; et al. Malnutrition and sarcopenia predict post-liver transplantation outcomes independently of the Model for End-stage Liver Disease score. J. Cachexia Sarcopenia Muscle 2017, 8, 113-121. [CrossRef] [PubMed] 
33. Tsien, C.; Garber, A.; Narayanan, A.; Shah, S.N.; Barnes, D.; Eghtesad, B.; Fung, J.; McCullough, A.J.; Dasarathy, S. Post-liver transplantation sarcopenia in cirrhosis: A prospective evaluation. J. Gastroenterol. Hepatol. 2014, 29, 1250-1257. [CrossRef] [PubMed]

34. Hanai, T.; Shiraki, M.; Ohnishi, S.; Miyazaki, T.; Ideta, T.; Kochi, T.; Imai, K.; Suetsugu, A.; Takai, K.; Moriwaki, H.; et al. Rapid skeletal muscle wasting predicts worse survival in patients with liver cirrhosis. Hepatol. Res. 2016, 46, 743-751. [CrossRef] [PubMed]

35. Nardelli, S.; Lattanzi, B.; Torrisi, S.; Greco, F.; Farcomeni, A.; Gioia, S.; Merli, M.; Riggio, O. Sarcopenia Is Risk Factor for De-velopment of Hepatic Encephalopathy After Transjugular Intrahepatic Portosystemic Shunt Placement. Clin. Gastroenterol. Hepatol. 2017, 15, 934-936. [CrossRef] [PubMed]

36. Wang, C.W.; Feng, S.; Covinsky, K.E.; Hayssen, H.; Zhou, L.-Q.; Yeh, B.M.; Lai, J.C. A Comparison of Muscle Function, Mass, and Quality in Liver Transplant Candidates. Transplantation 2016, 100, 1692-1698. [CrossRef]

37. Montano-Loza, A.J.; Angulo, P.; Meza-Junco, J.; Prado, C.M.M.; Sawyer, M.B.; Beaumont, C.; Esfandiari, N.; Ma, M.; Baracos, V.E. Sarcopenic obesity and myosteatosis are associated with higher mortality in patients with cirrhosis. J. Cachexia Sarcopenia Muscle 2016, 7, 126-135. [CrossRef]

38. Carey, E.J.; Lai, J.C.; Wang, C.W.; Dasarathy, S.; Lobach, I.; Montano-Loza, A.J.; Dunn, M.A.; Fitness, L.E.; Consortium, E.i.L.T. A multicenter study to define sarcopenia in patients with end-stage liver disease. Liver Transplant. 2017, 23, 625-633. [CrossRef]

39. Ebadi, M.; Wang, C.W.; Lai, J.C.; Dasarathy, S.; Kappus, M.R.; Dunn, M.A.; Carey, E.J.; Montano-Loza, A.J. Poor perfor-mance of psoas muscle index for identification of patients with higher waitlist mortality risk in cirrhosis. J. Cachexia Sarcopenia Muscle 2018, 9, 1053-1062. [CrossRef]

40. Fujiwara, N.; Nakagawa, H.; Kudo, Y.; Tateishi, R.; Taguri, M.; Watadani, T.; Nakagomi, R.; Kondo, M.; Nakatsuka, T.; Minami, T.; et al. Sarcopenia, intramuscular fat deposition, and visceral adiposity independently predict the outcomes of hepatocellular carcinoma. J. Hepatol. 2015, 63, 131-140. [CrossRef]

41. Beer, L.; Bastati, N.; Ba-Ssalamah, A.; Pötter-Lang, S.; Lampichler, K.; Bican, Y.; Lauber, D.; Hodge, J.; Binter, T.; Pomej, K.; et al. MRI-defined sarcopenia predicts mortality in patients with chronic liver disease. Liver Int. 2020, 40, 2797-2807. [CrossRef] [PubMed]

42. Praktiknjo, M.; Book, M.A.; Luetkens, J.; Pohlmann, A.; Meyer, C.; Thomas, D.; Jansen, C.; Feist, A.; Chang, J.; Grimm, J.; et al. Fat-free muscle mass in magnetic resonance imaging predicts acute-on-chronic liver failure and survival in decompensated cirrhosis. Hepatology 2018, 67, 1014-1026. [CrossRef] [PubMed]

43. Paternostro, R.; Lampichler, K.; Bardach, C.; Asenbaum, U.; Landler, C.; Bauer, D.; Mandorfer, M.; Schwarzer, R.; Trauner, M.; Reiberger, T.; et al. The value of different CT-based methods for diagnosing low muscle mass and predicting mortality in patients with cirrhosis. Liver Int. 2019, 39, 2374-2385. [CrossRef] [PubMed]

44. Shen, W.; Punyanitya, M.; Wang, Z.; Gallagher, D.; St.-Onge, M.-P.; Albu, J.; Heymsfield, S.B.; Heshka, S. Total body skeletal muscle and adipose tissue volumes: Estimation from a single abdominal cross-sectional image. J. Appl. Physiol. 2004, 97, 2333-2338. [CrossRef] [PubMed]

45. Choe, E.K.; Kang, H.Y.; Park, B.; Yang, J.I.; Kim, J.S. The Association between Nonalcoholic Fatty Liver Disease and CT-Measured Skeletal Muscle Mass. J. Clin. Med. 2018, 7, 310. [CrossRef] [PubMed]

46. Janssen, I.; Heymsfield, S.B.; Wang, Z.; Ross, R. Skeletal muscle mass and distribution in 468 men and women aged 18-88 yr. J. Appl. Physiol. 2000, 89, 81-88. [CrossRef] [PubMed]

47. Goodpaster, B.H.; Carlson, C.L.; Visser, M.; Kelley, D.E.; Scherzinger, A.; Harris, T.B.; Stamm, E.; Newman, A.B. Attenuation of skeletal muscle and strength in the elderly: The Health ABC Study. J. Appl. Physiol. 2001, 90, 2157-2165. [CrossRef]

48. Martin, L.; Birdsell, L.; Macdonald, N.; Reiman, T.; Clandinin, M.T.; McCargar, L.J.; Murphy, R.; Ghosh, S.; Sawyer, M.B.; Baracos, V. Cancer Cachexia in the Age of Obesity: Skeletal Muscle Depletion Is a Powerful Prognostic Factor, Independent of Body Mass Index. J. Clin. Oncol. 2013, 31, 1539-1547. [CrossRef]

49. Carias, S.; Castellanos, A.L.; Vilchez, V.; Nair, R.; Cruz, A.C.D.; Watkins, J.; Barrett, T.; Trushar, P.; Esser, K.; Gedaly, R. Nonalcoholic steatohepatitis is strongly associated with sarcopenic obesity in patients with cirrhosis undergoing liver transplant evaluation. J. Gastroenterol. Hepatol. 2016, 31, 628-633. [CrossRef]

50. Prado, C.M.M.; Lieffers, J.R.; McCargar, L.J.; Reiman, T.; Sawyer, M.B.; Martin, L.; Baracos, V. Prevalence and clinical impli-cations of sarcopenic obesity in patients with solid tumours of the respiratory and gastrointestinal tracts: A population-based study. Lancet Oncol. 2008, 9, 629-635. [CrossRef]

51. Pfirrmann, C.W.; Schmid, M.R.; Zanetti, M.; Jost, B.; Gerber, C.; Hodler, J. Assessment of Fat Content in Supraspinatus Mus-cle with Proton MR Spectroscopy in Asymptomatic Volunteers and Patients with Supraspinatus Tendon Lesions. Radiology 2004, 232, 709-715. [CrossRef] [PubMed]

52. Karampinos, D.C.; Ruschke, S.; Dieckmeyer, M.; Diefenbach, M.; Franz, D.; Gersing, A.S.; Krug, R.; Baum, T. Quantitative MRI and spectroscopy of bone marrow. J. Magn. Reson. Imaging 2018, 47, 332-353. [CrossRef] [PubMed]

53. Fischer, M.A.; Nanz, D.; Shimakawa, A.; Schirmer, T.; Guggenberger, R.; Chhabra, A.; Carrino, J.A.; Andreisek, G. Quantifi-cation of Muscle Fat in Patients with Low Back Pain: Comparison of Multi-Echo MR Imaging with Single-Voxel MR Spec-troscopy. Radiology 2013, 266, 555-563. [CrossRef] [PubMed]

54. Ma, J. Dixon techniques for water and fat imaging. J. Magn. Reson. Imaging 2008, 28, 543-558. [CrossRef] [PubMed] 
55. Fischer, M.A.A.; Pfirrmann, C.W.; Espinosa, N.; Raptis, D.A.; Buck, F.M. Dixon-based MRI for assessment of muscle-fat con-tent in phantoms, healthy volunteers and patients with achillodynia: Comparison to visual assessment of calf muscle quality. Eur. Radiol. 2014, 24, 1366-1375. [CrossRef]

56. Khan, A.I.; Reiter, D.A.; Sekhar, A.; Sharma, P.; Safdar, N.M.; Patil, D.H.; Psutka, S.P.; Small, W.C.; Bilen, M.A.; Ogan, K.; et al. MRI quantitation of abdominal skeletal muscle correlates with CT-based analysis: Implications for sarcopenia measure-ment. Appl. Physiol. Nutr. Metab. 2019, 44, 814-819. [CrossRef]

57. Faron, A.; Sprinkart, A.M.; Kuetting, D.L.R.; Feisst, A.; Isaak, A.; Endler, C.; Chang, J.; Nowak, S.; Block, W.; Thomas, D.; et al. Body composition analysis using CT and MRI: Intra-individual intermodal comparison of muscle mass and myosteatosis. Sci. Rep. 2020, 10, 1-10. [CrossRef]

58. Finanger, E.L.; Russman, B.S.; Forbes, S.C.; Rooney, W.D.; Walter, G.A.; Vandenborne, K. Use of Skeletal Muscle MRI in Di-agnosis and Monitoring Disease Progression in Duchenne Muscular Dystrophy. Phys. Med. Rehabili. Clin. N. Am. 2012, 23, 1-10. [CrossRef]

59. Dahlqvist, J.R.; Widholm, P.; Leinhard, O.D.; Vissing, J. MRI in Neuromuscular Diseases: An Emerging Diagnostic Tool and Biomarker for Prognosis and Efficacy. Ann. Neurol. 2020, 88, 669-681. [CrossRef]

60. Smitaman, E.; Flores, D.V.; Gómez, C.M.; Pathria, M.N. MR Imaging of Atraumatic Muscle Disorders. RadioGraphics 2018, 38, 500-522. [CrossRef]

61. Rossi, F.; Valdora, F.; Barabino, E.; Calabrese, M.; Tagliafico, A. Muscle mass estimation on breast magnetic resonance imag-ing in breast cancer patients: Comparison between psoas muscle area on computer tomography and pectoralis muscle area on MRI. Eur. Radiol. 2019, 29, 494-500. [CrossRef] [PubMed]

62. Faron, A.; Pieper, C.C.; Schmeel, F.C.; Sprinkart, A.M.; Kuetting, D.L.R.; Fimmers, R.; Trebicka, J.; Schild, H.H.; Meyer, C.; Thomas, D.; et al. Fat-free muscle area measured by magnetic resonance imaging predicts overall survival of patients under-going radioembolization of colorectal cancer liver metastases. Eur. Radiol. 2019, 29, 4709-4717. [CrossRef]

63. Zwart, A.T.; Becker, J.-N.; Lamers, M.J.; Dierckx, R.A.J.O.; De Bock, G.H.; Halmos, G.B.; Van Der Hoorn, A. Skeletal muscle mass and sarcopenia can be determined with 1.5-T and 3-T neck MRI scans, in the event that no neck CT scan is performed. Eur. Radiol. 2020, 1-10. [CrossRef]

64. Park, J.; Gil, J.R.; Shin, Y.; Won, S.E.; Huh, J.; You, M.-W.; Park, H.J.; Sung, Y.S.; Kim, K.W. Reliable and robust method for abdominal muscle mass quantification using CT/MRI: An explorative study in healthy subjects. PLoS ONE 2019, 14, e0222042. [CrossRef] [PubMed]

65. Bering, T.; Diniz, K.G.; Coelho, M.P.P.; Vieira, D.A.; Soares, M.M.S.; Kakehasi, A.M.; Correia, M.I.T.; Teixeira, R.; Queiroz, D.M.; Rocha, G.A.; et al. Association between pre-sarcopenia, sarcopenia, and bone mineral density in patients with chronic hepatitis C. J. Cachexia Sarcopenia Muscle 2018, 9, 255-268. [CrossRef]

66. Ohara, M.; Suda, G.; Kimura, M.; Maehara, O.; Shimazaki, T.; Shigesawa, T.; Suzuki, K.; Nakamura, A.; Kawagishi, N.; Nakai, M.; et al. Analysis of the optimal psoas muscle mass index cut-off values, as measured by computed tomography, for the diagnosis of loss of skeletal muscle mass in Japanese people. Hepatol. Res. 2020, 50, 715-725. [CrossRef] [PubMed]

67. Morsbach, F.; Zhang, Y.-H.; Nowik, P.; Martin, L.; Lindqvist, C.; Svensson, A.; Christensen, R.H. Influence of tube potential on CT body composition analysis. Nutrition 2018, 53, 9-13. [CrossRef] [PubMed]

68. Morsbach, F.; Zhang, Y.-H.; Martin, L.; Lindqvist, C.; Christensen, R.H. Body composition evaluation with computed tomog-raphy: Contrast media and slice thickness cause methodological errors. Nutrition 2019, 59, 50-55. [CrossRef]

69. Rollins, K.E.; Javanmard-Emamghissi, H.; Awwad, A.; Macdonald, I.A.; Fearon, K.C.; Lobo, D.N. Body composition meas-urement using computed tomography: Does the phase of the scan matter? Nutrition 2017, 41, 37-44. [CrossRef]

70. Van Vugt, J.L.A.; Braak, R.R.J.C.V.D.; Schippers, H.J.; Veen, K.M.; Levolger, S.; De Bruin, R.W.; Koek, M.; Niessen, W.; Ijzer-mans, J.N.M.; Willemsen, F.E. Contrast-enhancement influences skeletal muscle density, but not skeletal muscle mass, meas-urements on computed tomography. Clin. Nutr. 2018, 37, 1707-1714. [CrossRef]

71. Buehring, B.; Siglinsky, E.; Krueger, D.; Evans, W.; Hellerstein, M.; Yamada, Y.; Binkley, N. Comparison of muscle/lean mass measurement methods: Correlation with functional and biochemical testing. Osteoporos. Int. 2018, 29, 675-683. [CrossRef] [PubMed]

72. Hayashida, I.; Tanimoto, Y.; Takahashi, Y.; Kusabiraki, T.; Tamaki, J. Correlation between Muscle Strength and Muscle Mass, and Their Association with Walking Speed, in Community-Dwelling Elderly Japanese Individuals. PLoS ONE 2014, 9, e111810. [CrossRef] [PubMed]

73. Goodpaster, B.H.; Park, S.W.; Harris, T.B.; Kritchevsky, S.B.; Nevitt, M.; Schwartz, A.V.; Simonsick, E.M.; Tylavsky, F.A.; Visser, M.; Newman, A.B.; et al. The Loss of Skeletal Muscle Strength, Mass, and Quality in Older Adults: The Health, Aging and Body Composition Study. J. Gerontol. Ser. A Biol. Sci. Med. Sci. 2006, 61, 1059-1064. [CrossRef] [PubMed]

74. Visser, M.; Deeg, D.J.; Lips, P.; Harris, T.B.; Bouter, L.M. Skeletal Muscle Mass and Muscle Strength in Relation to Low-er-Extremity Performance in Older Men and Women. J. Am. Geriatr. Soc. 2000, 48, 381-386. [CrossRef]

75. Mijnarends, D.M.; Meijers, J.M.; Halfens, R.; Ter Borg, S.; Luiking, Y.C.; Verlaan, S.; Schoberer, D.; Jentoft, A.J.C.; Van Loon, L.J.; Schols, J.M. Validity and Reliability of Tools to Measure Muscle Mass, Strength, and Physical Performance in Communi-tyDwelling Older People: A Systematic Review. J. Am. Med. Dir. Assoc. 2013, 14, 170-178. [CrossRef] 